occasion to point out that "Dr. Mond's foundation was a most important accession to the resources which had been placed at the command of the institution for the advancement of chemical and physical science. The Royal Institution has long enjoyed a world-wide reputation, thanks to the marvellous work of the succession of illustrious men whose researches carried on within its walls have very largely contributed to secure and maintain for this country a foremost position as a source of great discoveries and important advances in science and its applications."

Mr. Robert Mond was nominated in the deed of trust honorary secretary for life.

The managers appointed the late Lord Rayleigh and Sir James Dewar the directors without remuneration.

The following is a selection of inquiries executed in the Davy-Faraday Research Laboratory communicated to scientific societies by fellows of the Royal Society:-Dr. H. Debus, "Contributions to the History of Glyoxalic Acid"; Hugo Muller, "Quercitol, Cocositol, Inositol, Flavon"; Horace T. Brown, "Starch: Its Transformations and Derivatives"; J. Y. Buchanan, "The Specific Gravity of Soluble Salts"; J. Emerson Reynolds, "Silicon Researches"; J. E. Petavel, "Standards of Light" and "Gaseous Explosive Mixtures"; A. Scott, "Atomic Weight of Carbon, etc."; W. J. Russell, "Action of Wood on Photographic Plates in the Dark, etc."'

The following papers have been published:-A. Croft Hill, "Reversibility of Enzyme or Ferment Action, etc."; W. Wahl, "Optical Investigations of Solidified Gases, etc."; W. Gluud, "Derivatives of Allylamine, Phenylglycine, etc."; Sir J. C. Bose, "The Response of Inorganic Matter to Stimulus, etc."; Miss Ida Smedley, "Colour Derivatives of Fluorene"; and .Miss A. Everett, "Colour Photometry."

\section{THE INTERNATIONAL CATALOGUE OF SCIENTIFIC LITERATURE.}

THE International Catalogue of Scientific Literature was constituted in Igoo at an International Conference held in London under the auspices of the Royal Society. It is a unique attempt to secure an accurate and exhaustive bibliography of pure science by international co-operation, each country being responsible for the indexing of its own literature. Each volume contains an author index and a subject index. An annual issue is composed of seventeen volumes indexing the seventeen branches into which science is divided for convenience of reference. The books and papers catalogued are those published since January I, Igor, pafers published before that date being indexed in the Royal Society's Catalogue of Scientific Papers.

The control of the catalogue is in the hands of an international council composed of one representative from each country taking part in the work. This council appoints an executive committee, which meets in London, but each of the countries co-operating has its own regional bureau to prepare index cards and send them to a central bureau in London for publication. Since the foundation of the catalogue about three million such cards have been received from the bureaux. More than two hundred volumes have been published.

Until the outbreak of the war in I9I4 more than thirty countries were taking part in preparing the catalogue, and the harmony with which they worked together is one of the most remarkable features of the enterprise. Even the Russo-Japanese War did not hinder the delegates of Russia and Japan from meeting at the conferences.

Although the recent war and the present condition of Europe create a difficult position for all international undertakings, it is much to be hoped that means may be found for continuing the work of the catalogue on an international basis, and without sacrificing those distinctive features which have met with such widespread appreciation.

\section{THE TROPICAL DISEASES BUREAU.}

$T$ HE Tropical Diseases Bureau came into existence in July, I9I2, as a development of the Sleeping Sickness Bureau founded in 1908. The main function of the bureau has been to review current papers on tropical diseases, i.e. exotic diseases occurring in the tropics and sub-tropics. The medium of publication is the Tropical Diseases Bulletin, now in its fourteenth volume. The Bulletin, which appears monthly, contains classified summaries of all papers within its scope which come under notice. Each subject is in charge of a "sectional editor," whose initials are appended to his summaries. Thus the results of the most recent researches on tropical disease in every country, new methods of treatment, and improved means of prevention quickly become available for the remote worker in the tropics. Critical reviews of books are also published.

The bureau issues also the Tropical Veterinary Bul. letin quarterly, the object of which is to deal with the diseases of domestic animals in the tropics in the same way as the Tropical Diseases Bulletin does with the diseases of man.

The bureau maintains a library under the charge of Capt. R. L. Sheppard, which contains complete or nearly complete files of all the tropical medical journals, in addition to others, some two hundred series in all, and a large number of reports and reprints. Though the library is mainly intended for the use of the sectional editors, it is open to any inquirer without formality.

The bureau is under the management of a committee appointed by the Secretary of State for the Colonies, the expert members of which are Sir John Rose Bradford, Sir David Bruce, Sir Havelock Charles, Sir Wm. Leishman, Sir Patrick Manson, and, representing veterinary medicine, Sir John M'Fadyean and Sir Stewart Stockman. Dr. A. G. Bagshawe is the director. It is maintained by a grant in aid from the Imperial Treasury and by contributions from the Governments of India, the Sudan, the Union of South Africa, and certain colonies and protectorates, to which copies of its publications are supplied gratis. By the general public the Tropical Diseases Bulletin can be obtained at an annual subscription of a guinea, and the Tropical Veterinary Bulletin at tos.

The offices of the bureau are at present situated at the Imperial Institute, South Kensington.

\section{WOMEN AT CAMBRIDGE.}

IN February, I896, the council of the Senate reported the receipt of four memorials relating to the admission of women to degrees. A syndicate was appointed to consider the question, and in February, I897, the majority reported recommending that degrees should be conferred on women by diploma, but not that they should become members of the University on the same terms as men. The liveliest interest in and opposition to these proposals were occasioned, and a discussion lasting three days took place in the Senate House. Finally, in May, I897, the report

$$
\text { NO. 26IO, VOL. IO4] }
$$


was rejected by the Senate, amid scenes of enthusiasm and disorder, by a majority of 1707 to $66 \mathrm{I}$.

In May, I9I9, the council reported the receipt of two memorials relating to the same subject, and proposed the appointment of a syndicate to consider it. The first memorial stated:- "We believe that the time has passed for the adoption of half-measures, and that women should be admitted to full membership of the University." In the second, objection was taken to the "attempt to force a hasty conclusion on a prejudged issue," and the suggestion made that a solution might be found by allowing women to obtain degrees without becoming full members of the University. This suggestion-which is made now by those who in 1897 opposed the granting of degrees to women at all-is practically the same as that which was rejected by a large majority then, and illustrates how far the attitude towards women has changed in twenty-two years. There are few now who would dare openly to advocate the exclusion of women from the recognition righitly due to their study and their services to learning.

On Thursday, October 30, a discussion on the subject was held in the Senate House. It is clear that a large progressive body of opinion is in favour of removing all restrictions on the studies of women and on their just recognition by the University. It is also clear. however, that there is still an underlying opposition to the idea of a mixed university, which will manifest itself in proposals designed to shelve the question temporarily by the adoption of halfmeasures. There can be little doubt that in the end all restrictions will be removed; and there are many who believe that it will be wiser and more generous for the University now to allow women the full membership they demand than to have the change forced upon it by outside influence, e.g. through the coming Royal Commission.

\section{NOTES.}

ANNOUNCEMENT of the approaching fiftieth anniversary of the foundation of NATURF was made in a letter sent a few weeks ago to the presidents of a number of scientific societies, official heads of British universities, and other representatives of progressive knowledge, most of whom are among the contributors to the columns of this journal. The result of this communication has been that we have received numerous cordial messages of congratulation, many of them containing interesting reminiscences itssociated with Nature, and all most appreciative of the services it affords to scientific workers. It was hoped that space could have been found to publish these messages this week, but this has proved impracticable. We believe, however, that these testimonies to the close attention paid to the contents of NATURE will interest a wide scientific public, and therefore propose to place a selection from them before our readers in next week's issue.

THE general arrangement of Notes in these columns follows the principle of from man to machine; early paragraphs are concerned with current topics and events, and these are followed successively by Notes on subjects relating to biological, physical, and engineering sciences. The articles on scientific progress which we have been fortunate enough to secure for this issue are arranged in much the same order, so that each has a relationship to the contributions which precede and follow it. In addition to the descriptive articles concerned with different fields of scientific activity, short accounts are given of a few important British institutions established for research purposes NO. 26 IO, VOL. IO4] since Nature was first published. These articles will, we think, serve to increase the value of this jubilee number as an epitome of outstanding developments of scientific work during the past fifty years.

ON Wednesday, October 29, Mr. Balfour was inaugurated Chancellor of Cambridge University. In a letter to the Vice-Chancellor dated October 25 he had written:- "In so far as lifelong devotion to the University, unceasing interest in its welfare, and pride in its great services to learning be sufficient qualifications for that high post, I am not unfitted to fill it." His election was unopposed. In presenting the Letters Patent the Vice-Chancellor dwelt upon the needs of the University and upon the possibility of utilising the learning available in the University more fully in the service of the Empire. The new Chancellor agreed that it is the business of the com. munity to make easier the path of those who have shown what the sound learning and scientific training of a university can do for a national cause, but at the same time he felt that, in the main, Cambridge would have to trust, and could well trust, its own powers in the coming arduous days of peace. In all departments of national activity, but especially in the scientific study of the mechanical, economic, chemical, medical, or physical problems of the last five years, our universities-and not least Cambridge--have earned a position in the national estimation which they have never held before. This position carries great opportunities and great obligations with it. The interest of the next few years and their influence on the future history of education and human know. ledge are immense. There will undoubtedly be a strong tendency towards the adoption of a more technical education and towards the teaching of "practical" subjects in a university course; this tendency cannot, and must not, be opposed, but at the same time it is most earnestly to be desired that our universities should keep before the eyes of hrir students the three chief motives for the acquisition and improvement of knowledge: a pleasure in knowledge for its own sake, a sure faith that no attem't to acquire and improve knowledge is vain, and a reasoned belief in the power of knowledge to help and elevate mankind. Cambridge has chosen wisely in electing a Chancellor in whom these motives are so strong, and who possesses in a high degree the power and opportunity of keeping them before the eyes of the best of his countrymen.

Memorial tablets to Lord Lister to be erected at University College, London, will be unveilea on Tuesday, November Ir, by Sir George Makins, president of the Royal College of Surgeons, and Sir J. J. Thomson, president of the Royal Society. The Duke of Bedford, president of the Lister Memorial Committee, will preside.

The Very Rev. W. R. Inge, Dean of St. Paul's, has been appointed Romanes lecturer for 1920 at the University of Oxford. The date and subiect of his lecture will be announced later. The late Camden professor of ancient history, Mr. F. J. Haverfield, has bequeathed the residue of his estate, subject to certain charges, in trust to the University for the advancement of the study of Romano-British antiquities.

Mr. W. R. COOPER has just retired from the editorial chair of the Electrician, having decided to devote the whole of his time to his consulting practice. He was appointed editor of our contemporary in 1906 and under his editorship the journal has represented electrical science at its best, as well as progressive practice. He will be succeeded by Mr. F. H. Masters, 